\title{
Utilization of Wireless Sensor Network to Monitor Citarum River Quality for Milkfish Cultivation in Karawang Regency
}

\author{
Rafi Amartya Santosa ${ }^{1}$, Rizky Ariyan Qurais Shihab ${ }^{2}$, Adamzah Suyuti Bakar ${ }^{3}$, \\ Joni Welman Simatupang ${ }^{*}$ \\ 1,2,3,4 Program Studi Teknik Elektro, Fakultas Teknik, President University, Cikarang - 17530, Indonesia \\ *Corresponding email: joniwsmtp@ president.ac.id
}

Received: August 26, 2021

Accepted: October 13, 2021

\begin{abstract}
The purpose of this research (study) is to demonstrate the superiority of the wireless sensor network (WSN) technology method over the laboratory method in monitoring the water quality of the Citarum River in Karawang. To monitor the Citarum river water quality, government of Karawang regency conducted a test by taking the sample water to the laboratory. It seems to be such a conventional method. With the results of the BOD value obtained from the $D L H K$ data, which is $47.93 \mathrm{mg} / \mathrm{L}$, of course it will be a problem for the development of milkfish. However, an advanced method using Wireless Sensor Network (WSN) technology seems to be an alternative. Basically, this technology can monitor the water quality in real-time using multiple parameters and help cultivators to monitor the water used in milkfish cultivation. Of course WSN technology is more efficient than waiting for laboratory results. Therefore, if this technology is applied, the data will be obtained in real time. Of course the data can be processed and monitored directly to determine the quality of the water used. In terms of cost, this technology can be built at a moderate cost compared to laboratory work. Keywords: Citarum river, wireless sensor network, monitoring, milkfish, Karawang regency
\end{abstract}

\begin{abstract}
Abstrak
Tujuan penelitian ini adalah untuk menunjukkan keunggulan metode teknologi jaringan sensor nirkabel dibandingkan metode laboratorium dalam pemantauan kualitas air Sungai Citarum di Karawang. Untuk memantau kualitas air sungai Citarum, Pemkab Karawang melakukan pengujian dengan membawa air ke laboratorium, ini adalah metode tradisional. Dengan hasil nilai BOD yang didapatkan dari data $D L H K$ yaitu sebesar $47.93 \mathrm{mg} / \mathrm{L}$, tentu itu akan menjadi masalah untuk perkembangan ikan bandeng. Namun ada alternatif yang disebut dengan cara lanjutan dengan menggunakan teknologi jaringan sensor nirkabel. Teknologi ini dapat memantau kualitas air secara real-time dengan berbagai parameter, dan tentunya akan sangat membantu pembudidaya untuk memantau air yang digunakan dalam budidaya ikan bandeng. Tentu saja teknologi WSN lebih efisien daripada menunggu hasil laboratorium. Oleh karena itu jika teknologi ini diterapkan, data akan didapatkan secara realtime. Tentu data tersebut dapat diolah dan dipantau langsung untuk mengetahui kualitas air yang digunakan. Dari segi biaya, teknologi ini dapat dibangun dengan membutuhkan biaya yang sedang jika dibandingkan dengan pekerjaan laboratorium.
\end{abstract}

Kata Kunci: Sungai Citarum, Jaringan sensor nirkabel, pemantauan, Ikan bandeng, Pemkab Karawang

\section{Introduction}

Citarum River is one of the longest and the largest river in Indonesia which bordered with West Java Province. Citarum river length from the slopes of Mount Wayang, which is in Bandung Regency ends around the mouth of the Java Sea, which is at Muara Gembong, Bekasi Regency. Karawang Regency is a coastal area and is one of the locations that is flowed by the Citarum river. Geographically, Karawang seems to be potential to develop fishery resources, especially aquaculture. River water is widely used for daily purposes, such as reservoirs, transportation facilities, rice fields irrigation, livestock and fish farming needs [1]. In its utilization, Citarum river is widely used in the aquaculture sector, especially fishponds. Pond cultivation is a potential activity to increase the economy. It can be done by utilizing resources that are close to water sources, such as rivers, lakes, and even the sea. It is important to be note that Karawang Regency is one of the district where milkfish is produced. The local community hopes that the utilization of milkfish pond cultivation can become a source of their livelihoods that further can increase the amount of regional income. 
Milkfish is a leading fish in the fish farming sector. Labelled as a superior fish, currently milkfish performs a high economic value. due to its taste and high nutritious level which includes $24 \%$ protein and $10.58 \%$ fat. Therefore, the demand for milkfish consumption continue to increase from year to year [2]. However, its cultivation still has several problems including pests, diseases, and high eutrophication in which excessive use of chemicals components affect water quality. The problem of water quality also affects the quality and cause the quality of milkfish from the beginning to the harvest to decline. Management of water quality in the aquaculture sector is very important because it can increase production in the success of cultivation [3]. To maintain water quality in milkfish cultivation, it is necessary to change the water and check the water quality both physically and chemically on a regular basis. Therefore, cultivators are required to be able to check water quality in real-time. Currently, the water quality of the Citarum River can be categorized as a fairly polluted river. Monitoring of water quality is very necessary on a regular basis so that farmers can know the situation and condition of their ponds. This is done so that the cultivators can take an action and anticipate it. Because if the quality of the water used in cultivating the fish is not in accordance with the parameters of the milkfish that should be, of course it can affect the health and development of the milkfish in the future.

In addition to land being the main factor for establishing a pond cultivation business, of course there must be technology to support the pond cultivation business. The technology used by its cultivators is still very traditional and certainly requires a lot of money and time. However, along with technological developments, there is now technology that can monitor water quality in real-time and of course this will greatly help cultivators to monitor the water used in their fish cultivation. This technology is the Wireless Sensor Network (WSN). The function of the WSN is to monitor the environment through various parameters, such as temperature, acidity, oxygen content, etc. [4]. In this study, researchers will compare the results of the water quality of the Citarum river which coincides at 5 (five) points in Karawang Regency such as Curug, Walahar, Teluk Jambe Suspension Bridge, Alun-Alun, and Tanjungpura Suspension Bridge which is sourced laboratory data Dinas Lingkungan Hidup dan Kebersihan (DLHK) of Karawang Regency with several parameters of life that are suitable for milkfish cultivation. Apart from using laboratory data, of course the researchers will discuss using literature methods on how the Wireless Sensor Network (WSN) which has been widely used can also monitor water quality regularly and can obtain information quickly and precisely without having to wait for laboratory results. So that the milkfish cultivator is able to take follow-up actions, so that the cultivation he is doing is able to produce quality results.

Based on the background description above, the problem formulation in this study based on the cultivation sector is as follows: (a) how can the Wireless Sensor Network (WSN) monitor water quality in Citarum river? and (b) what is the influence of the water quality of Citarum river on the cultivation and development of milkfish? Therefore, the objectives of this research activity is directed to make observations on the use of technology to assist in the cultivation sector by studying the use of WSN in a water quality monitoring system of Citarum river and knowing the influence of Citarum river water on the cultivation and development of milkfish. This research was conducted by means of a case study in Karawang regency and will be based on data interpretations and calculations. Then, at the end we will conclude whether the quality of river water affects the development and cultivation of milkfish and the use of Wireless Sensor Network (WSN) can measure the quality of river water in Karawang Regency.

\section{Literature Review \\ Wireless Sensor Network (WSN)}

Wireless Sensor Network (WSN) is a based network infrastructure wireless that is used to monitor situations in physical and environmental conditions, such as temperature, sound, pressure, and others that are widely distributed by means of combining sensors, microcontroller, memory, operating system, radio communication and an energy source in the form of an integrated battery [5]. Monitoring of water quality is one of interesting parts of the utility of WSN. Even though WSN is well established in its field, the use of WSN technology can bring about changes. Implementation of WSN for water quality monitoring has several major advantages compared with laboratory measurement:

1. WSN can measure simultaneously physical and chemical parameters such as (DO, turbidity, temperature, $\mathrm{pH}$ ) so that it does not take a long time compared to the laboratory.

2. Capability in terms of self-configuration will very simplify the process of water quality monitoring. 
There is no measurement process for each parameter, and of course it will shorten the overall time in terms of measuring water quality. The ability of WSN in self-configuration is expected that people can buy electronic components at the store and then install them immediately without any configuration difficulties. Thus, in general, the advantage of WSN is that it is affordable in terms of implementation as well as maintenance, because its setup does not require fixed infrastructure.

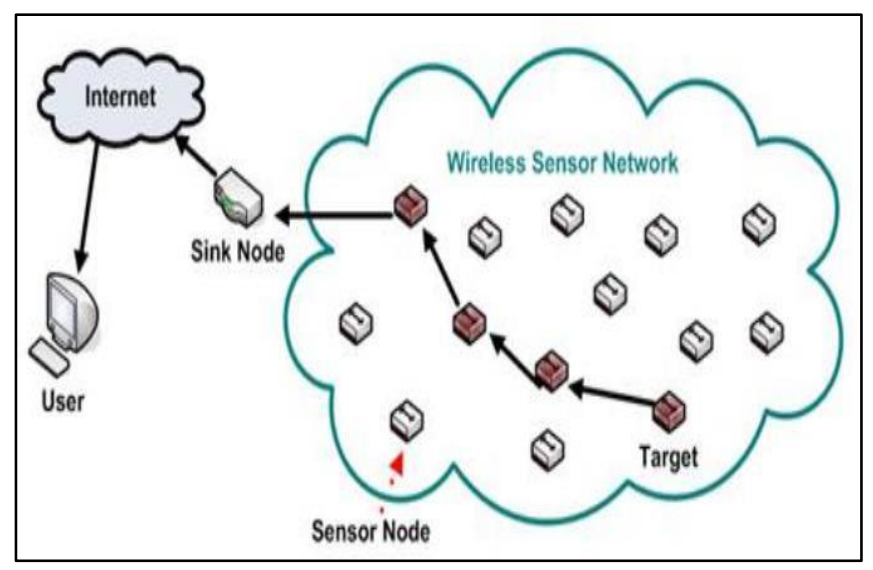

Figure 1. A typical of Wireless Sensor Network architecture [6].

The architecture that is structured to support the work process of the WSN consist of some elements as follow:

a. Sensor is a device that has the ability to convert energy into another form of energy. Has sensing ability which means having the ability to store, communicate, process and measure a quantity to be measured. The process is to convert the measured amount of energy which is then processed by the ADC into a quantized row of pulses which is then read by the microcontroller.

b. The microcontroller functions as a liaison by calculating, controlling and processing the connected devices.

c. Memory serves as additional storage. Basically, the microcontroller already has its own internal storage.

d. Transceiver functions to receive / send data as a radio with protocols used such as ISA100, IEEE 1451, ZigBee, 802.15.4, EnOcean and IETF RPL to other devices such as concentrators, wifi modems, and RF modems.

e. Operating System functions as software to support the running of each connected component, such as TinyOS, Contiki, Nano-RK, LiteOS, RTOS

f. Power Unit functions as power for the WSN system as a whole.

The development of WSN began with applications in the military field. Examples that have been used are large-scale marine surveillance systems to detect submarines and are also deployed for battle surveillance. Many WSN applications are applied in the field of control and monitoring for industry, equipment conditions, environmental habitats, pollution, and many more. Because WSN technology can reduce costs, WSN developments are now widely used in the commercial and civil fields [5]. Table $\mathbf{1}$ is a list of research related to WSN that has been widely used (implemented) from various sectors.

Table 1. Implementation of WSN in various sectors

\begin{tabular}{cccc}
\hline Author & Year & Implementation & Components \\
\hline $\begin{array}{c}\text { Perez } \text { et al. } \\
\text { [7] }\end{array}$ & 2011 & Ocean Sensing and Monitoring & $\begin{array}{c}\text { Sensors (temperature, pressure, salinity, } \\
\text { velocity, turbidity), GPRS, ZigBee, } \\
\text { Two Solar Panels }\end{array}$ \\
$\begin{array}{c}\text { Hulu } \text { et } \text { al. } \\
{[8]}\end{array}$ & 2015 & Monitoring volcanic & Sensors (acoustic, timing, P-phase) \\
\hline
\end{tabular}




\begin{tabular}{|c|c|c|c|}
\hline $\begin{array}{c}\text { Lloret et al. } \\
\text { [9] }\end{array}$ & 2011 & Marine Fish Farms Monitoring & Sensor the amount of pollution \\
\hline $\begin{array}{l}\text { Sumaryono \& } \\
\text { Widyawan } \\
{[5]}\end{array}$ & 2012 & Home Controlling & $\begin{array}{l}\text { IEEE 802.15.4, Sensor (temperature, } \\
\text { humidity, light), Atmel Atmega } \\
\text { Microcontroller 128L, } 2 \text { AA batteries }\end{array}$ \\
\hline $\begin{array}{l}\text { O'Connors et al. } \\
{[10]}\end{array}$ & 2012 & Water Quality Monitoring & $\begin{array}{l}\text { Sensors (temperature, conductivity, and } \\
\text { depth) }\end{array}$ \\
\hline $\begin{array}{c}\text { Guobao et al. } \\
{[11]}\end{array}$ & 2014 & Marine environment monitoring & $\begin{array}{c}\text { Sensors (Temperature, salinity, pH, } \\
\text { DO), ZigBee, Battery }\end{array}$ \\
\hline
\end{tabular}

According to Sumaryono and Widyawan [5], the Wireless Sensor Network is a specially designed technology that is expected to have the following characteristics:

1. Can have low power to generate operations (energy harvesting)

2. Ability to operate in a strategic environment to be reached and monitored intensively

3. Can be mass produced and can monitor simultaneously with distributed

4. Ability to overcome node failures (fault tolerant)

5. In operation, existing nodes do not need regular maintenance (unattended operation)

6. There is mobility of the nodes, which means that new nodes will join the existing network without the need for manual configuration (self-configuration)

\section{Milkfish Cultivation}

\section{Criteria for milkfish cultivation}

Before cultivating milkfish, there are several criteria and stages that must be met to cultivate good milkfish, namely:

\section{The location must comply with applicable regulations}

In determining the location, the location of the pond must follow regional regulations related to cultivation. Make sure the location is not disturbed and disturbed by the interests around the pond. This is done to avoid conflicts that will arise at a later date. The construction of ponds is adjusted to government programs related to development carried out per period. Usually, this program takes place every 5 (five) years. In this case, coordination with related agencies also needs to be done. Based on the 1999 RAMSAR resolution, ponds that were cleared before 1999 are required to plant mangroves for at least 50\% of the area around the aquaculture being worked on. And ponds operating after 1999, pond owners are required to have evidence that pond processing does not damage the environment around the pond [12].

2. Regional etiquette in choosing a milkfish cultivation pond.

In establishing a pond, the owner must be able to assess whether the location is suitable to be used as a pond or not. The following are some regional requirements in choosing a milkfish aquaculture pond:

a. Ponds must be close to water sources, both from the sea, estuary rivers and various other water sources.

b. Ponds must not be located in areas prone to flooding or in areas prone to disasters.

c. Soil quality in the pond area must be good (not easily leak / porous). So that the pond can keep the water volume as desired.

d. The quality of soil that is very good for farming is soil that has a clay texture where the composition, sand, dust, clay and other soil constituents are balanced. Try to avoid areas having high levels of acid sulfate (high pyrite content), because high pyrite content can affect the condition of milkfish.

e. Try to keep the pond area very far from pollution, especially garbage and waste which has an influence on the quality of the water source flow.

After knowing the regional ethics for pond cultivation, of course cultivators must think about the accessibility of the pond. Accessibility is taken into account so that the pond is easily accessible and of course it needs to have sufficient facilities and infrastructure. it can accelerate the activities of pond farmers to get seeds and to sell their fishponds.

\section{Milkfish Seeds (NENER)}

Good milkfish cultivation must have superior fish seeds. Superior nener usually has a uniform size and has no defects, and also has to be agile. The easiest way to find stump seedlings is when the water is rotated in 
the container, the nener should move against the current. Usually, healthy nener has a full stomach and a healthy, transparent body color. Milkfish seeds have a minimum age of 2 weeks and 4 days and reach 1.6 $\mathrm{cm}$ in length. The time for transferring seeds is usually done in the morning or just before evening. This is done to reduce the temperature difference when moving. Usually, the transfer of nener is carried out in a large plastic bag and inside it is filled with oxygen so that the nener can survive longer.

4. Water Quality Management

The development cycle of milkfish is often related to the water used. In maintaining the quality of cultivated water, the pond area should have mangrove plants with an area of $50 \%$ of the pond area if the pond is located around the sea. However, if the pond location is on land, efforts will be made to filter the water first in order to maintain the condition of the pond water. During cultivation, it is necessary to change the water and check the water quality at least 2-3 times a day so that we can know and regulate the conditions of the pond [12, 13]. Can be relied on to fill pond water. Based on the data received, the following (Table 2) is a list of water quality that is good for the development of milkfish:

Table 2. The life parameters of milkfish $[12,13]$

\begin{tabular}{|c|c|c|}
\hline Water quality & Optimal & Management \\
\hline Ammonia & $<0.01 \mathrm{mg} / 1$ & When changing water sources \\
\hline Total Organic Material & $20-25 \mathrm{mg} / 1$ & When changing sources water \\
\hline BOD & $<3 \mathrm{mg} / \mathrm{l}$ & \\
\hline Salinity & $5-25 \mathrm{ppt}$ & $\begin{array}{l}\text { At the turn of the water resources } \\
\text { and the incorporation of seawater } \\
\text { (salt) with fresh water }\end{array}$ \\
\hline Carbon Free & $<12 \mathrm{ppm}$ & \\
\hline Acidity & $7.5-8.5 \mathrm{pH}$ & Liming \\
\hline Brightness of & $30-40 \mathrm{~cm}$ & At the turn of the water sources \\
\hline Nitrate & $<10$ & \\
\hline Nitrite & $<1$ & \\
\hline Oxygen dissolved & $4-8 \mathrm{mg} / 1$ & At change of water source \\
\hline Salinity & $15-30 \mathrm{ppt}$ & \\
\hline Temperature & $28-32{ }^{\circ} \mathrm{C}$ & \\
\hline Total Alkanity & $50-500 \mathrm{ppm}$ & \\
\hline
\end{tabular}

\section{Water Quality Control}

a. Turbidity

Turbidity is a physical characteristic of water that not only harms fish but also makes water quality unproductive because it blocks the entry of sunlight. This is caused by a lot of suspended particles so that they change the appearance of the color and become dirty in the water. There are 3 ways to deal with water turbidity in fishponds:

1. Creating a place for water to settle before flowing into the pond.

2. Planting some plants in the pond, this can reduce the turbidity caused by the mud.

3. Routine water changes

If the amounts of plankton in the pond is very small, it is necessary to grow phytoplankton so that the waters become fertile.

b. Salinity of

Milkfish is a fish that is Euryhalien, which means an organism that can adapt to salinity levels. Milkfish has an adaptation to the salt content of water and is very resistant to high intensity and very short shaking. Milkfish can survive in freshwater levels and in areas with salt levels $>70$ promil (unit of Salinity) in Table 3 . The salinity and osmotic pressure of water are closely related. The higher the osmotic pressure, the higher the salt content.

c. Temperature

Temperature has a very important role in the life of milkfish. The level of fish development is in line with the high level of temperature and temperature stability. If it is very small, the solubility of oxygen will also 
be small. The water temperature in the pond area varies widely. It is caused by the influence of the weather in the area. Usually, the optimal temperature for milkfish growth ranges from $28-32{ }^{\circ} \mathrm{C}$.

d. DO (Dissolved Oxygen)

DO is a limiting factor in water. If there is a change in concentration, it will have a direct effect which can lead to death in aquatic organisms. Oxygen in waters can be obtained through:

1. Direct diffusion through the air.

2. Oxygen that is bound through condensation (rainwater)

3. The photosynthesis of green plants in water such as pythoplankton.

The dissolved oxygen is closely related to the salt content and temperature in the water. The higher the oxygen solubility, the lower the temperature and salinity will be. There are several ways to overcome the lack of oxygen in the ponds, namely making waterwheels and changing water with better quality water.

e. Acidity Level / pH

The acidity level in the fishpond is caused by the soil around the pond. Milkfish is very sensitive to changes in water $\mathrm{pH}$. If the $\mathrm{pH}$ of the water in the pond is not optimal, then action must be taken, such as: spreading the lime content which has a suitable level to stabilize the $\mathrm{pH}$ of the water environment. and it could also be done by replacing the water in the pond with new water from a water source that has a higher $\mathrm{pH}$. Do not accumulate organic materials / tools, because this can cause an excessive increase in $\mathrm{pH}$.

f. $\mathrm{CO}_{2}$ (Carbon Dioxide)

$\mathrm{CO}_{2}$ is bent into free $\mathrm{CO}_{2}, \mathrm{CO}_{2}$ bicarbonate and $\mathrm{CO}_{2}$ carbonate. The amount of free $\mathrm{CO}_{2}$ is rarely calculated. This is caused by the high level of plants in the pond. So that $\mathrm{CO}_{2}$ will be released directly into the air during photosynthesis. the strong nature of the buffer in the water also affects $\mathrm{CO}_{2}$ levels. Free $\mathrm{CO}_{2}$ that enters trapped in the water will be converted into $\mathrm{CO}_{2}$ bicarconate and $\mathrm{CO}_{2}$ monocarbonate which do not have much effect in the water. The level of $\mathrm{CO}_{2}$ of milkfish in water is not more than $12 \mathrm{ppm}$.

\section{Eradication of Pests and Diseases}

Fish diseases are the most important disturbance in cultivation, of course it can cause losses in production. The emergence of disease can be caused by several factors, including environmental conditions, the condition itself, and pantogenic organisms. The types of diseases and prevention commonly reported are as follows:

1) Types of disease: On dirty scales/skin

Cause $\quad \rightarrow \quad$ Caligus $S p$, Piscicolla $S p$

Symptom $\rightarrow$ Decreased appetite, damaged scales

Treatment $\rightarrow \quad$ Prepare about 20 grams of saga stems and leaves, then mash them. smooth and add $1 \mathrm{~L}$ of $\mathrm{NaCl}$ solution and soak and wait for about 2-3 hours

2) Type of disease: Fin on fish tail

Cause $\rightarrow$ Fiorrot disease

Symptoms $\rightarrow$ Damage to the fins, especially in the tail of the fish

Treatment $\rightarrow$ Prepare the roots, stems and leaves of saga a lot 15-20 grams, then finely ground with the addition of 1 liter of $\mathrm{NaCl}$ solution and additional salt solution, then soak for 1-2 hours until you see a difference.

\section{Measurement of Water Quality}

Laboratory

The laboratory is a facility used for research activities, observations, on a scientific basis which is intended as an approach between theory and practice of the various sciences being tested. Measurements in the laboratory include clean water, wastewater, soil, and air quality with parameters that have been accredited by KAN (National Accreditation Committee) so that test results can be recognized in accordance with international standards. Here are some tools used to detect water quality (see in Table 3). 
Table 3. Water quality measurement tools

\begin{tabular}{|c|c|c|c|}
\hline No. & Name & Measuring & Unit \\
\hline 1. & Thermometer & Temperature & ${ }^{\circ} \mathrm{C}$ \\
\hline 2. & $\begin{array}{l}\mathrm{pH} \text { meter, } \mathrm{pH} \text { ep, } \mathrm{pH} \\
\text { indicator }\end{array}$ & water $\mathrm{pH}$ & \\
\hline 3. & DO meter & oxygen & $\mathrm{mg} /$ liter \\
\hline & Winkler titration Dissolved & & (ppm) \\
\hline 4. & Sechidish Jakson chip & Brightness / turbidity & $\mathrm{cm}$ \\
\hline 5. & $\begin{array}{l}\text { Turbidimeter } \\
\text { Salino meter } \\
\text { Refractometer }\end{array}$ & Salt & $\begin{array}{l}\text { Promil Level / } \\
\mathrm{ppt} / \\
0 / 00\end{array}$ \\
\hline
\end{tabular}

\section{WSN for water quality monitoring}

Implementation of WSN to monitor water quality has been a lot from previous research. The water quality research conducted by P. Mompoloki in Botswana, used the Waspmote device made by Libelium, then the sensor monitoring data were displayed in real time on a PC [14]. On the other hand, there is a similar research conducted by Z. Lieping on river water monitoring systems in Guangxi, China. This study uses the MSP module as a processing unit and the CC2530 module which acts as a wireless amplifier connected using the Zigbee protocol [15]. Following, the researchers created a table related to research on WSN-based water quality monitoring that has been widely carried out (Table 4).

Table 4. WSN-based Water Quality Research

\begin{tabular}{|c|c|c|c|c|}
\hline Author & Year & Title & Component & Main Features \\
\hline $\begin{array}{l}\text { Jin et al } \\
\text { [16]. }\end{array}$ & 2010 & $\begin{array}{l}\text { A Novel } \\
\text { Design of } \\
\text { Water } \\
\text { Environment } \\
\text { Monitoring } \\
\text { System Based } \\
\text { on WSN }\end{array}$ & $\begin{array}{l}\text { sensors (Temperature, } \\
\text { pH, DO, and salinity), } \\
\text { GPRS, ZigBee, Battery }\end{array}$ & $\begin{array}{l}\text { Monitoring using two wireless } \\
\text { communication such as GPRS } \\
\text { and ZigBee }\end{array}$ \\
\hline $\begin{array}{l}\text { Hendrawati et al. } \\
\text { [17] }\end{array}$ & 2019 & $\begin{array}{l}\text { River Water } \\
\text { Pollution } \\
\text { Monitoring } \\
\text { System Based } \\
\text { on Wireless } \\
\text { Sensor } \\
\text { Technology and } \\
\text { Internet-of- } \\
\text { Things }\end{array}$ & $\begin{array}{l}\text { Sensor (pH, Turbidity, } \\
\text { Temperature), Arduino } \\
\text { Uno R3, Arduino Mega, } \\
\text { Li-Ion } \\
\text { nRF24L01 + }+ \text { Lattery, } \\
\text { antenna, Wifi ESP8266 }\end{array}$ & $\begin{array}{lll}\begin{array}{l}\text { Monitoring } \\
\text { website }\end{array} & \text { data } & \text { through } \\
\text { application } & & \text { android } \\
\text { apd } & & \end{array}$ \\
\hline $\begin{array}{l}\text { Syafiqoh et al. } \\
\text { [18] }\end{array}$ & 2018 & $\begin{array}{l}\text { Pengembangan } \\
\text { Wireless Sensor } \\
\text { Network Berbasis } \\
\quad \text { Internet of Things } \\
\text { untuk Sistem } \\
\text { Pemantauan Kualitas } \\
\text { Air dan Tanah } \\
\text { Pertanian }\end{array}$ & $\begin{array}{l}\text { Sensor ( } \mathrm{pH}, \\
\text { temperature, humidity), } \\
\text { ESP8266 }\end{array}$ & $\begin{array}{l}\text { Monitoring using modul wifi } \\
\text { ESP8266 at a low price and } \\
\text { also has a speed of } 80 \mathrm{MHz}\end{array}$ \\
\hline $\begin{array}{l}\text { Maulana et al. } \\
\text { [19] }\end{array}$ & 2016 & $\begin{array}{l}\text { Online } \\
\text { Monitoring of } \\
\text { Water Quality in } \\
\text { Shrimp Culture } \\
\text { WSN and IoT } \\
\text { Based }\end{array}$ & $\begin{array}{l}\text { Sensor (DO, pH, } \\
\text { conductivity } \\
\text { temperature), Xbee Pro, } \\
\text { Arduino Uno, Rasberry } \\
\text { Pi 2, Solar Panel }\end{array}$ & $\begin{array}{l}\text { Online Monitoring via website } \\
\text { (Laptop, PC or mobile device) }\end{array}$ \\
\hline $\begin{array}{l}\text { Alkandari et al. } \\
\text { [20] }\end{array}$ & 2012 & $\begin{array}{l}\text { Water } \\
\text { monitoring } \\
\text { system using }\end{array}$ & $\begin{array}{l}\text { Sensors (temperature, } \\
\text { DO, and } \mathrm{pH} \text {, ZigBee }\end{array}$ & $\begin{array}{l}\text { Using the Zigbee protocol and } \\
\text { using high-capacity solar } \\
\text { panels }\end{array}$ \\
\hline
\end{tabular}


Wireless Sensor Network (WSN): Case study of Kuwait beaches.

Adin et al. 2019 [21]
Physical
Parameter
Monitoring
System Fish
Pond Water
using Wireless
Sensor Networks
based on the
LoRaProtocol

802.11 Ethernet radio, solar panels

Sensor (temperature, acidity, turbidity, and DO), LoRa Protocol, Arduino nano,
Wide area monitoring using the LoRa protocol

Based on existing research related to quality monitoring WSN-based water, but in the milkfish farming sector, no one has discussed the use of WSN technology to help monitor water quality for their aquaculture ponds. Therefore, this research is expected to provide insights to pond farmers to utilize this technology to improve the quality produced from their cultivation.

\section{Research Method}

The research methodology includes the stages of how we are reaching the research objectives. Following are stages related to this research:

First, doing literature study through primary sources such as journals from the results of several studies by producing much data and conducting case studies on the Wireless Sensor Network (WSN) for monitoring water quality and milkfish cultivation. Second, conducting interviews by producing primary data on January to March 2021 obtained from the Environment and Sanitation Office (DLHK) of Karawang Regency regarding the quality of water in the Citarum river in Karawang Regency which is the location of the case study in this research. Interviews were conducted in 2 (two) days starting 27-28 April 2021, interviews were conducted at the DLHK office with several sources, namely Mrs. Desire as KASI (Section Head) of Water and Soil Pollution Control and Mr. Nur Wibawanto as Head of Sub-Division for Administration of the Environmental Laboratory of the UPTD. Third, summing up the results and discussion related to the data by calculating the average water quality of the Citarum river and concluding with the feasibility of milkfish cultivation and concluding the use of WSN technology in water quality monitoring.

\section{Results and Discussion \\ Citarum River Water Quality}

According to Mrs. Desire, the Environment and Sanitation Office of Karawang Regency has 5 monitoring locations for the water quality of Citarum river, including Curug, Walahar, Teluk Jambe Suspension Bridge, Karawang Square, and Tanjung Pura Suspension Bridge. Then the researchers filtered the parameter data and adjusted it to several parameters in the life parameters of milkfish in Table 2, so that we could find out the feasibility of the life of milkfish cultivation in Karawang district. The following Table $\mathbf{5}$ to $\mathbf{9}$ are Citarum river water quality results in 5 locations from the period of January to March 2021 (based on data provided):

Table 5. Curug dam waterfall (Location 1)

\begin{tabular}{llllll}
\hline \multirow{2}{*}{ No. } & \multirow{2}{*}{ Parameter } & \multirow{2}{*}{ Unit } & \multicolumn{3}{c}{ Month } \\
\cline { 4 - 6 } & & & January & February & March \\
\hline 1. & PH & & 7.2 & 7.3 & $7: 29$ \\
2. & Temperature & ${ }^{\circ} \mathrm{C}$ & 30 & 30.1 & 29.7 \\
3. & DO & $\mathrm{mg} / \mathrm{L}$ & $2: 51$ & 4.7 & $5: 49$ \\
4. & BOD & $\mathrm{mg} / \mathrm{L}$ & 20 & 92 & 6 \\
5. & Nitrate & $\mathrm{mg} / \mathrm{L}$ & $0: 11$ & $0: 01$ & $0: 14$ \\
\hline
\end{tabular}


Table 6. Bridge Village Walahar (Location 2)

\begin{tabular}{llllll}
\hline \multirow{2}{*}{ No. } & \multirow{2}{*}{ Parameter } & \multirow{2}{*}{ Unit } & \multicolumn{3}{c}{ Month } \\
\cline { 4 - 6 } & & & January & February & March \\
\hline 1. & PH & & 7.1 & 7.81 & 6.87 \\
2. & Temperature & ${ }^{\circ} \mathrm{C}$ & 30.1 & 30.2 & 30.2 \\
3. & DO & $\mathrm{mg} / \mathrm{L}$ & 2.3 & 4.5 & $3: 23$ \\
4. & BOD & $\mathrm{mg} / \mathrm{L}$ & 17 & 87 & 5 \\
5. & Nitrate & $\mathrm{mg} / \mathrm{L}$ & 0.77 & $0: 01$ & $0: 24$ \\
\hline
\end{tabular}

Table 7. Suspension Bridge Teluk Jambe (Location 3)

\begin{tabular}{llllll}
\hline \multirow{2}{*}{ No. } & \multirow{2}{*}{ Parameter } & \multirow{2}{*}{ Unit } & \multicolumn{3}{c}{ Month } \\
\cline { 4 - 6 } & & & January & February & March \\
\hline 1. & PH & & $7: 15$ & $7: 15$ & $7: 05$ \\
2. & Temperature & ${ }^{\circ} \mathrm{C}$ & 30 & 30.1 & 31.4 \\
3. & DO & $\mathrm{mg} / \mathrm{L}$ & 2.71 & 4.61 & $4: 36$ \\
4. & BOD & $\mathrm{mg} / \mathrm{L}$ & 19 & 94 & 6 \\
5. & Nitrate & $\mathrm{mg} / \mathrm{L}$ & $0: 18$ & $0: 01$ & $0: 33$ \\
\hline
\end{tabular}

Table 8. Alun - Alun Karawang (Location 4)

\begin{tabular}{llllll}
\hline \multirow{2}{*}{ No. } & \multirow{2}{*}{ Parameter } & \multirow{2}{*}{ Unit } & \multicolumn{3}{c}{ Month } \\
\cline { 4 - 6 } & & & January & February & March \\
\hline 1. & PH & & 7.65 & 7.5 & $7: 14$ \\
2. & Temperature & ${ }^{\circ} \mathrm{C}$ & 27.8 & 30 & 29.1 \\
3. & DO & $\mathrm{mg} / \mathrm{L}$ & $2: 11$ & 4.2 & $4: 17$ \\
4. & BOD & $\mathrm{mg} / \mathrm{L}$ & 16 & 164 & 5 \\
5. & Nitrate & $\mathrm{mg} / \mathrm{L}$ & $0: 23$ & $0: 01$ & 0.3 \\
\hline
\end{tabular}

Table 9. Suspension Bridge Tanjung Pura (Location 5)

\begin{tabular}{|c|c|c|c|c|c|}
\hline \multirow{2}{*}{ No. } & \multirow{2}{*}{ Parameter } & \multirow{2}{*}{ Unit } & \multicolumn{3}{|c|}{ Month } \\
\hline & & & January & February & March \\
\hline 1. & $\mathrm{PH}$ & & 7.74 & 7.5 & 7.14 \\
\hline 2. & Temperature & ${ }^{\circ} \mathrm{C}$ & 30.2 & 30 & 29.1 \\
\hline 3. & DO & $\mathrm{mg} / \mathrm{L}$ & 2.71 & 4.2 & 4.17 \\
\hline 4. & BOD & $\mathrm{mg} / \mathrm{L}$ & 19 & 164 & 5 \\
\hline 5. & Nitrate & $\mathrm{mg} / \mathrm{L}$ & 0.03 & 0.01 & 0.3 \\
\hline
\end{tabular}

Table 10 is the after we analyzed by calculating the average of each parameter to know whether all of water quality monitoring locations in Karawang Regency can be used as a milkfish pond cultivation business. 
Table 10. Total Average Parameters in 5 monitoring locations of Karawang regency

\begin{tabular}{|c|c|c|c|c|c|c|c|}
\hline \multirow{3}{*}{ Parameters } & \multirow{3}{*}{ Unit } & \multicolumn{5}{|c|}{ Average } & \multirow{3}{*}{$\begin{array}{l}\text { Average } \\
\text { Total }\end{array}$} \\
\hline & & \multicolumn{5}{|c|}{ Location } & \\
\hline & & 1 & 2 & 3 & 4 & 5 & \\
\hline $\mathrm{PH}$ & & 7.26 & 7.26 & 7.1 & 7.46 & 7.46 & 7,312 \\
\hline Temperature & ${ }^{\circ} \mathrm{C}$ & 29.93 & 30.16 & 30.5 & 28.96 & 29.76 & 29.87 \\
\hline DO & $\mathrm{mg} / \mathrm{L}$ & 4.23 & 3.34 & 3.893 & 3.49 & 3.69 & 3.73 \\
\hline BOD & $\mathrm{mg} / \mathrm{L}$ & 39.3 & 36.3 & 39.67 & 61.67 & 62.67 & 47.93 \\
\hline Nitrate & $\mathrm{mg} / \mathrm{L}$ & 0.086 & 0.34 & 0.173 & 0.18 & 0.113 & 0.178 \\
\hline
\end{tabular}

Looking at the average results of each parameter that has been analyzed, there is one parameter according to the researcher, Citarum river water in Karawang regency cannot be used as a milkfish cultivation business by looking at the life parameters of milkfish in Table 2. That parameter is BOD (Biological Oxygen Demand). In addition to other main parameters, the BOD parameter has a role as an estimator of organic matter pollution carried out by irresponsible industries without going through adequate processing and if the indicator value is not in accordance with what has been set. Of course, there is a decreased in dissolved oxygen levels in the waters where oxygen is important for the life of air biota and aquatic ecosystems in general.

\section{Measurements of Water Quality In Laboratory Testing Method}

According to Mr. Nur Wibawanto, the laboratory of the Environmental and Cleanliness Service (DLHK) has two characteristics, namely commercial and service.

1. Commercial means that the laboratory provides services for companies or public places that require water quality testing. Usually, the quality test is used as a monitoring evaluation (MONEV) to monitor pollution around the place, of course all costs are borne by the person who submitted it.

2. Having a service nature means that the laboratory is willing if there are complaints from the public, and of course it must go through the procedures applied in the agency. As a community, for example, we have complaints related to the water quality, we must go to the complaints section in the department, then our complaints can be accepted by the laboratory. For fees on this property are free, which means that all costs are borne by the agency if the complaint is taken seriously.

If you want to test the water in laboratory, the costs incurred are in accordance with the desired parameters. The water quality test process in laboratory takes approximately about 2 weeks, equal with 14 working days.

\section{Using Wireless Sensor Network (WSN)}

There have been many studies related to WSN-based water quality monitoring, of course the process produced by WSN technology is different from the test process in the laboratory. This is because there are many uses of WSN in monitoring water quality. In this study, we refer to the WSN design that has been established by Hendrawati et al. (2019) in their paper with the title of "River Water Pollution Monitoring System Based on Wireless Sensor Technology and Internet-of-Things" [17]. Their research can help us in terms of monitoring water quality, because in terms of the components needed, the cost is quite affordable and also environmentally friendly. In addition, the data generated can be obtained through the website or android application, the data can be generated without waiting for a long process. Hopefully this technology is expected to help pond farmers in cultivating their milkfish.

Based on the explanation of each method, the following Table 11 is a comparison of the water quality monitoring methods carried out by the laboratory and WSN technology. Based on the Table 11, we can conclude that WSN technology is better in providing the fast data results for the users, measuring multiple parameters at once, but less accurate compared to lab test results. 
Table 11. Comparison of Laboratory and WSN Methods

\begin{tabular}{|c|c|c|c|c|c|}
\hline $\begin{array}{l}\text { Water quality } \\
\text { monitoring } \\
\text { methods }\end{array}$ & Size & Cost & Test type & Advantage & Limitations \\
\hline Laboratory & Big & Expensive & Off site & $\begin{array}{l}\text { - It has been } \\
\text { officially tested } \\
\text { - Get accurate results }\end{array}$ & $\begin{array}{l}\text { - High cost } \\
\text { because it fits the } \\
\text { parameters tested } \\
\text { - Waiting for } \\
\text { results within } 14 \\
\text { working days }\end{array}$ \\
\hline $\begin{array}{l}\text { Wireless Sensor } \\
\text { Network (WSN) }\end{array}$ & Portable & Cheap & In-site & $\begin{array}{l}\text { - Fast data results } \\
\text { - Reliable in } \\
\text { measurement } \\
\text { - Measure multiple } \\
\text { parameters at once } \\
\text { - Easy to apply } \\
\text { - Easy to care for }\end{array}$ & $\begin{array}{l}\text { - Depending on } \\
\text { the components } \\
\text { used, the wider } \\
\text { the test site, the } \\
\text { more components } \\
\text { will be used to } \\
\text { design the WSN }\end{array}$ \\
\hline
\end{tabular}

Source: Data analysis

\section{Conclusion and Suggestion}

Based on the results of research data that has been carried out, the BOD results are $47.93 \mathrm{mg} / \mathrm{L}$ and it can be concluded that the river water in the Citarum river which is located at 5 points in Karawang Regency does not meet the BOD criteria for milkfish cultivation. In fact, BOD is an important indicator to determine the quality of water from one place such as river. We can say that the water quality is very bad. Based on the results of the data, there are several places at a certain time that have the amount of DO that is less than the optimal limit. The lower the DO value, the less oxygen content in the water will make it difficult for the fish to breathe in the water. For other indicators such as temperature, $\mathrm{PH}$, and Nitrate $\left(\mathrm{NO}_{3}-\mathrm{N}\right)$ at these 5 points, it is considered very good for milkfish cultivation. And based on the research results, it is also found that the performance of WSN is superior and easier to use than the performance of laboratory results. Where testing using the laboratory requires more time and money, while with WSN we can minimize the use of time and costs. Hopefully the research insights related to the use of WSN for cultivation can be used by pond farmers to improve the quality of their cultivation.

\section{Acknowledgment}

The authors are grateful to Ms. Disa Evawani Lestari, English Faculty of President University for proof-reading this manuscript, and to Research Institute and Community Service (RICS) of President University for the support in publication.

\section{Abbreviations}

$\begin{array}{ll}\text { WSN } & \text { : Wireless Sensor Network } \\ \text { DLHK } & \text { : Dinas Lingkungan Hidup dan Kebersihan } \\ \text { BOD } & \text { : Biological Oxygen Demand } \\ \text { DO } & \text { : Dissolved Oxygen } \\ \text { MONEV } & : \text { Monitoring Evaluation }\end{array}$

\section{References}

[1] D. Hendrawan, "Kualitas Air Sungai Dan Situ Di DKI Jakarta," MAKARA Technol. Ser., vol. 9, no. 1, pp. 13-19, 2010, doi: 10.7454/mst.v9i1.315. 
[2] Hafiludin, "Analisis Kandungan Gizi Pada Ikan Bandeng Yang Berasal Dari Habitat Yang Berbeda," J. Kelaut., vol. 8, no. 1, pp. 37-43, 2015.

[3] ZI Salsabila. (2020, August 5). Pentingnya Pengelolaan Kualitas Air dalam Budidaya Ikan, [Online]. Tersedia: $\quad$ https://desaloano.com/pentingnya-pengelolaan-kualitas-air-dalam-budidaya-perikanan/ [Diakses tanggal 10 April 2021]

[4] S. Sridharan, "Water Quality Monitoring Using Wireless Sensor Network," International Journal of Advanced Research in Electronics and Communication Engineering (IJARECE), vol. 3, no. 4, pp. 399402, 2014.

[5] S. Sumaryono and Widyawan, "Pengembangan Wireless Sensor Network Untuk Aplikasi Home Controlling," Jurnal Ilmu Pengetahuan Dan Teknologi Tepat Guna, Universitas Gadjah Mada, vol. 2. pp. 45-53, 2012

[6] A. Sabiq and PN Budisejati, "Web Monitoring System of pH Level, Temperature and Color on River Water using Wireless Sensor Network," J. Teknol. dan Sist. Komput., vol. 5, no. 3, pp. 94-100, 2017, doi: 10.14710/jtsiskom.5.3.2017.94-100.

[7] Perez, C.A.; Jimenez, M.; Soto, F.; Torres, R.; López, J.A.; Iborra, A. A system for monitoring marine environments based on Wireless Sensor Networks. In Proceedings of the IEEE Conference on OCEANS, Santander, Spain, 6-9 June 2011; pp. 1-6..

[8] E. Hulu, B. Riyanto, and S. Widyantoro, "Wireless Sensor Networks For Volcano Activity Monitoring: A Survey,” Sci. J. Informatics, vol. 2, no. 1, pp. 53-62, 2015, doi: 10.15294/sji.v2i1.4528.

[9] Lloret, J.; Sendra, S.; Garcia, M.; Lloret, G. Group-based Underwater Wireless Sensor Network for Marine Fish Farms. In Proceedings of the 2011 IEEE GLOBECOM Workshops, Houston, TX, USA, 59 December 2011; pp. 115-119.

[10] O'Connor, E.; Zhang, D.; Smeaton, A.F.; O'Connor, N.E.; Regan, F. Multi-Modal Sensor Networks for More Effective Sensing in Irish Coastal and Freshwater Environments. In Proceedings of the IEEE Oceans, Hampton Roads, VA, USA, 14-19 October 2012; pp. 1-9.

[11] G. Xu, W. Shen, and X. Wang, "Applications of wireless sensor networks in marine environment monitoring: A survey," Sensors (Switzerland), vol. 14, no. 9, pp. 16932-16954, 2014, doi: 10.3390/s140916932.

[12] Tim Perikanan WWF-Indonesia, Budidaya Ikan Bandeng (Chanos chanos) Pada Tambak Ramah Lingkungan, Seri Panduan Perikanan Skala Kecil (Magazine), Versi 1, Desember 2014.

[13] A. P. Wahyuni, M. Firmansyah, N. Fattah, dan Hastuti, "Studi Kualitas Air Untuk Budidaya Ikan Bandeng (Chanos chanos Forsskal) di Tambak Kelurahan Samataring Kecamatan Sanjai Timur," Jurnal Agrominansia, 5(1), Juni 2020, pp.106-113, ISSN: 2527-4538.

[14] P. Mompoloki, Y. Abid, and C. Joseph, “A Wireless Sensor Network Solution for Monitoring Water Quality in Botswana," in 2016 3rd National Foundation for Science and Technology Development Conference on Information and Computer Science (NICS), Danang, Vietnam, 14-16 Sept 2016

[15] Z. Lieping, C. Peng, and P. Fei, "Design of Lijiang Water Environment Monitoring System Based on WSN," in 2016 Eighth International Conference on Measuring Technology and Mechatronics Automation (ICMTMA), Macau, China, 11-12 March 2016.

[16] Jin, N.; Ma, R.; Lv, Y.; Lou, X.; Wei, Q. A Novel Design of Water Environment Monitoring System Based on WSN. In Proceedings of the 2010 International Conference on Computer Design and Applications (ICCDA), Qinhuangdao, China, 25-27 June 2010; pp. 593-597

[17] T.D. Hendrawati, A. Rafi, A. Tahtawi, and F. Fadilah, "Sistem Monitoring Pencemaran Air Sungai Berbasis Teknologi Sensor Nirkabel dan Internet-of-Things," Ind. Res. Work. Natl. Semin., vol. 10, no. 1, pp. 286-292, 2019.

[18] Syafiqoh, U.; Sunardi.; Yudhana, A.(2018). Pengembangan Wireless Sensor Network Berbasis Internet of Things untuk Sistem Pemantauan Kualitas Air dan Tanah Pertanian. Jurnal Informatika: Jurnal Pengembangan IT (JPIT), Vol:.03, No.02, Mei 2018. DOI: http://dx.doi.org/10.30591/jpit.v3i2.878.g710

[19] Y.Y. Maulana, G. Wiranto, and D. Kurniawan, "Online Monitoring Kualitas Air Pada Budidaya Udang Berbasis WSN Dan IoT,” INKOM J. Informatics, Control Syst. Comput., vol. 10, no. 2, pp. 81-86, 2016.

[20] Alkandari, A.; Alnasheet, M.; Alabduljader, Y.; Moein, SM Water monitoring system using Wireless Sensor Network (WSN): Case study of Kuwait beaches. In Proceedings of the Second International 
Conference on Digital Information Processing and Communications (ICDIPC), Klaipeda City, Lithuania, 10-12 July 2012; pp. 10-15.

[21] D.T. Adin, A. Bhawiyuga, and W. Yahya, "Sistem Monitoring Parameter Fisik Air Kolam Ikan menggunakan Jaringan Sensor Nirkabel berbasis Protokol LoRa,” J. Pengemb. Teknol. Inf. dan Ilmu Komput., vol. 3, no. 6, pp. 5414-5420, 2019. 